BLS 34, No 1 2008. DOI: http://dx.doi.org/10.3765/bls.v34i1.3560

(published by the Berkeley Linguistics Society and the Linguistic Society of America)

\title{
Structural Case and the Typology of Possessive Constructions ${ }^{1}$
}

\author{
MAIA DUGUINE \\ U. Basque Country \& U. Nantes-Naoned
}

\section{Introduction}

This paper shows that, in the nominal domain, a strong correlation exists between three syntactic properties of possessor DPs: (i) the triggering of agreement, (ii) the availability of pro-drop and (iii) the possibility to extract them. I suggest that this distribution derives from a condition on structural case assignment to possessors.

First in Section 2 I discuss the two coexisting patterns of morphosyntactic realization of possessor-possessed relations found in a wide number of languages, identifying a descriptive generalization that had not been noticed previously in the literature. In Section 3 I develop an account in terms of a condition on structural case assignment, and finally in Section 4 I give empirical evidence that strengthens the claim that some but not all possessors are assigned structural case.

\section{Two Strategies for Possession and the Syntax of Possessors}

In many languages, possessive constructions of the type 'Mary's house' surface with an agreement morpheme attached to the 'head noun', which agrees in person and number with the possessor DP. I will refer to this type of morphological realization of possession as Pattern A(greement). The general schema can be represented as in (1) (word order is irrelevant), and is illustrated with Tzotzil (2): ${ }^{2}$

$$
\begin{aligned}
& \text { Pattern A(greement): } \\
& \text { S-tot li Xun-e } \\
& \text { 3-father ART Xun-CL } \\
& \text { 'Xun's father' }
\end{aligned}
$$

\footnotetext{
${ }^{1}$ I would like to thank Mark Baker, Aniko Csirmaz, Aritz Irurtzun, Nerea Madariaga, Myriam Uribe-Etxebarria, the audience at BLS 34, and also the audience at the $1^{\text {st }}$ Workshop of the European Research Nets in Linguistics (U. Basque Country, where part of this material was presented. This study has been developed thanks to the grant Juan San Martin by Udako Euskal Unibertsitatea \& Eibarko Udala and the project IT-210-07 of the Basque Government.

${ }^{2}$ Abbreviations: NOM: nominative, GEN: genitive; ACC: accusative, INTER: interrogative, L: linker, ART: article, LOC: locative, INFL: inflection, FUT: future, NMLZ: nominalizer, CL: clitic.
} 


\section{Maia Duguine}

\subsection{Generalization on Pattern A Possessors}

Interestingly, if we consider the behavior of possessors in this structure, a strong correlation emerges, that had not been noticed before in the literature. In languages such as Abaza, Hungarian, Nahuatl, Southern Quechua, a number of Mayan languages (Jacaltec, Itzaj, Tzotzil, Tzutujil), and some Austronesian languages (Boumaa Fijian, Chamorro), a possessor DP that triggers agreement can consistently be dropped and wh-extracted from the DP in which it appears (see Duguine 2007). ${ }^{3}$ This is illustrated in (3) with Tzotzil:

$$
\begin{aligned}
& \text { a. j-moch pro } \\
& \text { 1-basket 'my basket' }
\end{aligned}
$$

b. Buch'u av-il-be [s-tot $t]$ ?

who 2-see-io 3-father

'Whose father did you see?'

I propose to spell out this correlation as the following generalization:

\section{Generalization on Pattern A possessors:}

In the languages in which the possessum agrees in $\varphi$-features with its possessor DP, the possessor can be dropped and extracted.

But what happens when there is no agreement? In the following two sections, I will study some of the languages cited above which, alongside Pattern A, have a second strategy for the morphosyntactic realization of possessor-possessed relations, in which no agreement surfaces. By so doing, we will be able to compare different structures on the basis of minimal pairs, avoiding the interferences with independent, language-specific factors.

\subsection{Dialectal Variation in Quechua}

Quechua displays an interesting dialectal variation with regards to DP-internal agreement. In most dialects, possessive constructions follow what I have called the Pattern A. This is the case of Southern Quechua (SQ), as illustrated in (5) (cf. 2.1). However, Imbabura Quechua (IQ) constitutes an exception: as shown in (6), no agreement affix attaches to nouns in this dialect.

$$
\begin{aligned}
& \text { Maria-q wasi-n } \\
& \text { Maria-GEN house-3SG } \\
& \text { 'Maria's house' }
\end{aligned}
$$

\footnotetext{
${ }^{3}$ In Hungarian some possessors external to the DP do not seem to be extracted, but rather basegenerated there (Den Dikken 1999). There are also languages, such as Finnish, Palauan or Mohawk, that appear at first sight to constitute counterevidence to the generalization (4); in Duguine (2007) I argue that they can be accounted for independently.
} 
What is interesting for the issue under discussion is that, in contrast with SQ (7), possessors cannot be dropped or extracted in IQ. This is shown in (8):

\section{a. pro wasi-n \\ house-3SG \\ 'her/his house'}

b. Pi-qpa-ta reqsi-nki [ $t$ tura-n-ta]?

who-GEN-ACC know-2SG brother-3SG-ACC

'Whose brother do you know?'

(8)
a. *(pay-paj) wasi
he-GEN house
'his house'
b. *Pi-paj-taj riku-rka-ngui $[t$ alku-ta $]$ ? who-GEN-INTER see-PAST-2SG dog-ACC
'Whose dog did you see?'

\author{
Southern Quechua \\ (Sánchez 1996) \\ Southern Quechua \\ (Sánchez 1996) \\ Imbabura Quechua \\ (Cole 1985:115) \\ Imbabura Quechua \\ (Cole 1985:115)
}

Thus in IQ the absence of agreement correlates with the impossibility to drop and extract the possessor, contrarily to what we find in SQ, which follows Pattern A. This result, situated at the level of dialectal variation, becomes even more significant when found within a language, as is the case in some Austronesian languages. I discuss three such languages in the following section.

\subsection{Two Patterns in Austronesian Languages}

In addition to Pattern A, in Boumaa Fijian, Chamorro, and Palauan there is a second possessive construction in which a morpheme, also referred to as a 'linker', an 'association morpheme', a 'relator' etc. in the literature, appears between the possessed noun and the possessor DP; I will refer to it as Pattern L(inker). Both strategies are schematically represented in (9) (again, word order is irrelevant), and illustrated in (10)-(12) in each of the three languages.

$$
\begin{array}{ll}
\text { Pattern A(greement): } & \mathrm{NP}^{\text {possessum }}-\mathrm{AGR} \mathrm{DP}_{\varphi}{ }^{\text {possessor }} \\
\text { Pattern L(inker): } & \mathrm{NP}^{\text {possessum }}-\mathrm{L} \quad \mathrm{DP}_{\varphi}{ }^{\text {possessor }}
\end{array}
$$
a. i salappi'-ñiha i famalao'an ART money-3PL ART women 'the women's money'
b. i kareta-n Carmen agäga' ART car-L Carmen red 'Carmen's red car'
Chamorro Pattern A
(Chung 1998:31)
Chamorro Pattern L
(Chung 1998:47) 
a. a liga-na a gone.yalewa yai ART hand-3SG ART young girl this

Boumaa Fijian Pattern A

(Dixon 1988:121)

'the hand of this young girl'

b. a liga-i gone.yalewa yai ART hand-L young girl this 'the hand of this young girl'
a. a 'ole'es-el a Marta ART pencil-3SG ART Martha 'Martha's pencil'
b. a buk er a 'ekabi ART book L ART girl 'the girl's book'

Boumaa Fijian Pattern L

(Dixon 1988:123)

Palauan Pattern A

(Georgopoulos 1991:53)

Palauan Pattern L

(Georgopoulos 1991:31)

The presence of agreement correlates with the possibility to drop and extract the possessor, but what happens when there is no agreement, i.e. in Pattern L? Let us first analyze the facts regarding possessor dropping. Chung (1998:49) notes that in Chamorro "when the possessor is null ... then the possessed noun must exhibit possessor-noun agreement"; i.e. the possessor cannot be null in Pattern L. Likewise, Dixon (1988:36) notes that in Boumaa Fijian the linker "is suffixed to the possessed noun and is followed by the possessor"; i.e. the possessor must be overt. Finally, the same generalization is observed by Georgopoulos (1991:31) for Palauan: "a pronoun possessor is ... overt when it is object of the [linker]". That is, in all three languages the possessor cannot be dropped in Pattern L, contrary to what happens with Pattern A possessors, as seen in 2.1 and illustrated in (13):
a. Agupa' i kumpliaños-ña pro tomorrow ART birthday-3SG
'Tomorrow is his birthday.'
ART hand-3SG
'his/her hand'
b. a liga-na pro
c. a 'ole'es-em pro
ART pencil-2SG
'your pencil'

\section{Chamorro Pattern A \\ (Chung 1998:31)}

Boumaa Fijian Pattern A

(Dixon 1988:121)

Palauan Pattern A

(Georgopoulos 1991:53)

Likewise, we find the same correlation between the absence of agreement and the impossibility of extraction: Pattern L possessors cannot be extracted, while, as was shown in 2.1, Pattern A possessors can. The Chamorro data in (14a-b) illustrate this correlation very clearly: hayi 'who' cannot be extracted when it is introduced by a linker but it can when the possessed noun agrees with it.
a. *Hayi un-yulang [muñika-n $t]$ ? who INFL-break doll-L 'Whose doll did you break?'

\section{Chamorro Pattern L (Sandra Chung p.c.)}


b. Hayi ti man-mäguf [famagon-ña $t$ ]? who not INFL-happy children-3SG 'Whose children are unhappy?'

The same correlation is found in Boumaa Fijian: while Pattern L possessors must remain to the right of the linker (15a), Pattern A possessors can be extracted (15b). (Given that Palauan is a wh-in-situ language (Georgopoulos 1991), it cannot be tested for extraction.)

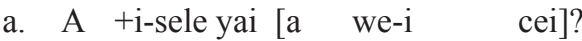 ART knife this ART belonging-L who Boumaa Fijian Pattern L
(Dixon 1988:171) 'This knife, it is whose?'
b. O cei a o-na +i-sele yai? ART who ART belonging-3SG knife this 'Whose is this knife?'
Boumaa Fijian Pattern A
(Dixon 1988:171)

Summarizing, in the Austronesian languages Boumaa Fijian, Chamorro and Palauan, depending on the whether the possession relation is realized by means of agreement or not, it will be possible to drop or extract the possessor. Interestingly, this is the same opposition that was introduced in 2.2 between SQ and IQ. These conclusions are summarized in the table in (16).

\begin{tabular}{|l|c|c|c|}
\hline \multicolumn{2}{|c|}{} & Poss. drop & Poss. extraction \\
\hline \multicolumn{2}{|c|}{ Agreement (Pattern A) } & $\checkmark$ & $\checkmark$ \\
\hline \multirow{2}{*}{ No agreement } & Imbabura Quechua & $x$ & $\times$ \\
\cline { 2 - 4 } & Autronesian Pattern L & $x$ & $\times$ \\
\hline
\end{tabular}

The resulting picture is that Pattern A possessors can be dropped and extracted, whereas other types of possessors cannot. What does this distribution follow from? The strong correlation between agreement and pro-drop is not very surprising, as the intuition that the pro-drop and the (rich) agreement phenomena are related is quite well supported empirically. What is more surprising, in fact, is the correlation between agreement and extraction (cf. however Rizzi 1990). It could be argued, for instance, that the extraction facts are not the result of genuine extraction but are cases of resumption by a little pro. This hypothesis has the advantage of explaining the correlation between the possibility of (apparent) extraction and pro-drop, and thus, it can transitively account for the correlation between agreement and extraction. However, the data from Chamorro show that these structures do not involve pro-drop but rather genuine extraction. First, if whpossessors were doubled by a pro and did not involve movement, we would expect no island effects, contrary to facts (17). 


\section{Maia Duguine}

*Hayi pära un-hanao [pära guma'-ña $t]$ ?

Chamorro

who FUT INFL-go to house-3SG

'Whose house will you go to?'

A second piece of evidence against a resumption analysis comes from a specific fact about Chamorro: as illustrated in (18), possessor-extraction is possible unless the DP from which it is extracted is headed by an overt article (cf. Chung 1991, 1998). This cannot be explained under a resumption analysis, specially knowing that possessors can be dropped in the same configuration (see (13a) above). ${ }^{4}$

$$
\begin{aligned}
& \text { *Hayi ti man-mäguf [i famagon-ña } t] \text { ? } \\
& \text { who not INFL-happy ART children-3SG } \\
& \text { 'Whose children are unhappy?' }
\end{aligned}
$$

Given the facts presented above, I propose the following generalization, which is more precise than the generalization on Pattern A previously given in (4):

(19) Generalization on languages with Pattern A: In the languages in which the possessum can agree in $\varphi$-features with its possessor DP, the possessor can only be dropped or extracted in agreement configurations.

Note also that the fact that the two patterns can coexist in the same language shows that the properties of possessor DPs with regard to extraction and pro-drop cannot be be said to derive from language-particular factors but are to be related to the morphosyntactic properties of the construction in which they appear.

In section 3, I propose that (19) derives from a condition on structural case.

\section{Case Condition on Possessor Drop and Extraction}

What is there behind the correlation between agreement and the possibility to drop and extract a possessor? First of all, the DP-internal agreement facts in Pattern A suggest that in a parallel fashion to what happens in the clause, there are agree operations in the nominal domain (cf. Szabolcsi 1994, Baker 1996, Sánchez 1996, Chung 1998, Gavruseva 2000 a.o.). This implies that, in terms of the operation AGREE (cf. Chomsky 2000, 2001), in these structures a head $\mathrm{H}^{\mathrm{o}}$ with uninterpretable $\varphi$-features values them against the possessor DP. Inversely, the absence of agreement in the same language can be taken to reflect the complete absence of $\varphi$-AGREE. If this is correct, the generalization (19) can be reinterpreted as follows: extraction and dropping of a possessor take place in configurations

\footnotetext{
${ }^{4}$ The account cannot either be based simply on the availability of an 'escape hatch' in the left periphery of the DP, given that there are languages, such as English or German, in which whereas extraction from DPs is possible, showing that there actually is an escape hatch (cf. (i)), extraction of possessor DPs is barred (cf. (ii)) (but see Gavruseva (2000) for a mixed account):

(i) Who did you see [a picture of]?

(ii) *Whose did you see [picture]?
} 


\section{Structural Case and the Typology of Possessive Constructions}

where it is a probe for $\varphi$-AGREE. Could thus $\varphi$-AGREE be the condition for dropping and extracting possessors? Not directly: AGREE operations are asymmetric, they do not affect the goal. But still, there is a syntactic operation that does affect the goal DP: structural case assignment. Is there in consequence a causal relationship between structural case assignment and possessor-drop and extraction? The so-called George-Kornfilt hypothesis - by which agreement and structural case are intimately connected (cf. George \& Kornfilt 1981, Schütze 1997, Chomsky 2000, 2001) -, suggests that this hypothesis is on the right track. That is, if structural case and agreement are the two sides of the same coin, it is expected that whenever a DP triggers agreement, it is also assigned structural case. This, in turn, suggests that the syntactic behavior of possessors with regards to pro-drop and extraction is related to their being (or not) assigned structural case: ${ }^{5}$

(20) Case condition on pro-drop and extraction of possessor DPs: A possessor DP can be dropped or extracted if and only if it bears Structural Case.

Note that (20) implies that possessor DPs are not always assigned structural case. In IQ and the Austronesian Pattern L, possessors cannot be dropped or extracted: this means that there is no structural case-assigning head in these structures. ${ }^{6,7}$ The two different patterns can be represented as in (21) and (22). ${ }^{8}$

$$
\begin{aligned}
& {\left[\mathrm { DP } ^ { \mathrm { o } } \left[\mathrm{HP}^{\mathrm{o}} \mathrm{H}_{[-\varphi ;+ \text { Case }]}\left[\mathrm{NP} \mathrm{DP}_{[+\varphi ;- \text {-Case }]} \ldots \mathrm{N}\right]\right.\right.} \\
& \text { a. }\left[\mathrm { DPP } ^ { \mathrm { o } } \left[\mathrm{HP}^{\mathrm{o}}\left[\mathrm{NP} \mathrm{DP}_{[+\varphi ;- \text { Case }} \ldots \mathrm{N}\right]\right.\right. \\
& \text { b. }\left[\mathrm{DP}^{\mathrm{o}}\left[\mathrm{DP}^{\mathrm{o}} \mathrm{DP}_{[+\varphi ;- \text { Case }]} \ldots \mathrm{N}\right]\right.
\end{aligned}
$$

In Pattern A (21), $\mathrm{H}^{\circ}$, which has a structural case feature [+Case], agrees with the possessor DP and in turn values the unvalued case feature [-Case] of the DP. In contrast, the pattern in (22) can involve two different settings: either $\mathrm{H}^{\circ}$ is present but it does not have $\varphi$ - and case-features (22a) or $\mathrm{H}^{\circ}$ is not projected at all (22b). In either case, structural case is not assigned to the possessor. ${ }^{9}$

If the hypothesis we have proposed is correct, this means that there is a strong parallelism between the structure of clauses and the nominal structure in (21) in

\footnotetext{
5 At this point, the following question arises: what principled explanation is there behind the causal relation in (20)? This question will not be studied here; still, it is possible that structural case plays a role of 'anchoring' for DPs, that permits them to be 'silent' (as pro or a trace) at PF.

${ }^{6}$ There could be languages with two such heads in the nominal domain: cf. Baker (1996:26970).

${ }^{7}$ Note that this conclusion fits nicely with the hypothesis that in the clause domain the number of heads with $[-\varphi]$ and [+Case] can vary crosslinguistically (cf. Béjar 2003, Bianchi 2006).

${ }^{8}$ AGREE in (21) is followed by N-raising, resulting in the attachment of the affix to N.

${ }^{9}$ Not valuing Case features does not lead to crash: those DPs that are not assigned structural case will have theta-related or default morphological case (Schütze 2001). Note that the same happens with $\varphi$-features: the absence of valuation can lead to default agreement (cf. Béjar 2003).
} 
Maia Duguine

that both have a structural case-marked DP (cf. Szabolcsi 1994, Abney 1987); crucially however, this parallelism does not extend to all types of nominal structures: there will be no DP with structural case in (22).

In this section, we have suggested that the ability for possessor DP to be dropped and extracted is related to the possibility of being assigned structural case. Next, we will see additional evidence that strengthens this hypothesis.

\section{Variation in the Marking of Possessors}

Above, I took the George-Kornfilt hypothesis to constitute evidence in favor of the case condition on possessor-drop and extraction in (20). In this section, I give some additional evidence in support of that hypothesis; specifically, I will show that Pattern A possessors behave actually like structural case-marked clausal arguments do, whereas IQ and Austronesian Pattern L possessors do not.

It is interesting to note, first of all, that Pattern A possessors generally bear a morphological case that corresponds to a clausal structural case. This is what we find in Abaza, Hungarian, Mohawk, Nahuatl, Itzaj, Jacaltec, Tzotzil and Tzutujil, where subjects and possessors surface with the same null case (nominative or ergative), but it is also what we find in Inuktitut and Yup'ik, where subjects and possessors bear overt ergative case (Johns 1992 and Abney 1987 respectively). ${ }^{10}$ When we turn to the languages with two strategies discussed in 2.1 and 2.2, what we can see is that Pattern A possessors show the same behavior as subjects with regards to case-marking whereas Pattern L possessors do not. Consider first the Chamorro data in (23)-(24). In Chamorro, both clausal subjects and possessors are marked with what Chung (1998) calls 'unmarked case' (23):

$$
\begin{aligned}
& \text { a. Ha-li'i' si Juan i pätgun lahi. } \\
& \text { INFL-seeUNMARKED.CASE Juan ART child MALE } \\
& \text { 'Juan saw the boy.' } \\
& \text { b. i haga-ña si Rita } \\
& \text { ART daughter-3SG UNMARKED.CASE Rita } \\
& \text { 'Rita's daughter' } \\
& \text { i haga-n Rita } \\
& \text { ART daughter-L Rita } \\
& \text { 'Rita's daughter' }
\end{aligned}
$$

\section{Chamorro Subject (Chung 1998:22)}

Chamorro Pattern A (Chung 1998:49)

Chamorro Pattern L (Chung 1998:49)

That both clausal subjects and Pattern A possessors surface with unmarked case is particularly relevant, given that Pattern L possessors are never marked with unmarked case (24). These data thus suggest that in Chamorro Pattern A possessors are assigned structural case but Pattern $\mathrm{L}$ possessors are not.

Let us now turn to Quechua. At first glance this language does not seem to confirm the distribution between two types of possessors. As shown in (25)-(26),

\footnotetext{
${ }^{10}$ In Hungarian some possessors surface with a dative marker (Szabolcsi 1994).
} 
main clause subjects surface with nominative case while possessors surface with genitive case both in SQ (Pattern A) and IQ.
a. Nuqa-ø papa-ta ranti-ni
'I buy potatoes.'
'Juan ate meat.'
a. Maria-q wasi-n
Maria-GEN house-3SG
'Maria's house'
b. Juzi-paj warmi
José-GEN wife
'José's wife'

I-NOM potato-ACC buy-1SG

b. Juan-ø aycha-ta miku-rka

Juan-NOM meat-ACC eat-3SG

(26)

\author{
Southern Quechua \\ (Sánchez 1996) \\ Imbabura Quechua \\ (Hermon 1985:21) \\ Southern Quechua \\ (Sánchez 1996) \\ Imbabura Quechua \\ (Cole 1985:115)
}

However, even if SQ possessors do not pattern with subjects in the morphological manifestation of case, they do so in that they are assigned structural case. The evidence comes from embedded nominalized clauses, where subjects surface with genitive case, but are structural case-marked (cf. Lefebvre \& Muysken 1989). ${ }^{11}$

[Xwan-pa hamu-na-n-ta] yacha-ni.

Southern Quechua

Juan-GEN come-NMLZ-3-ACC know-1SG

(Lefebvre \& Muysken 1989:17)

'I know that Juan is to come.'
[Maria- $\varnothing$ kay-pi ka-j-ta] ya-ni.
Maria-NOM here-in be-NMLZ-ACC think-1SG
'I think that Maria is here.'

Imbabura Quechua

(Hermon 1985:23)

If the embedded subject in (27) has structural case, this means that genitive in SQ is the morphological realization of a structural case. Hence, the possessor in (25) surfaces with the same morphological case some structural case-marked subjects do. On the contrary, in IQ embedded subjects bear (null) nominative case (28), then genitive is apparently not a structural case in this dialect. Consequently, the case that appears on the possessor in IQ (26b) must be of a different nature than the genitive case that surfaces on the possessor in SQ (26a).

Another piece of evidence in favor of the account of the generalization (19) in terms of the condition on structural case in (20) comes from Boumaa Fijian. Here there is no overt case marking that differentiates the DPs, but the idea is that if there is some condition that DPs must fulfill specifically when they are assigned structural case, then we expect Pattern A possessors - but not other types of possessors - to be subject to the same condition. As we will see now, this seems to be the case. In Bouma Fijian, subject and object DPs are always headed by an

\footnotetext{
${ }^{11}$ Genitive has three allomorphs in SQ: - $q$, -pa, and -qpa (Lefebvre \& Muysken 1989:78).
} 
Maia Duguine

overt article (29) (cf. Dixon 1988:114-116). As shown in (30)-(31), while Pattern A possessors also are (30), Pattern L possessors are not (cf. (31), and also (11)).

era la'o a gone

Boumaa Fijian Subject

3PL go ART child

(Dixon 1988:33)

'The youth is going'

a liga-na a gone.yalewa yai

ART hand-3SG ART young.girl this

Boumaa Fijian Pattern A

'the hands of this young girl'

a liga-i gone.yalewa yai

(Dixon 1988:121)

ART hand-L young.girl this

'the hands of this young girl'

Boumaa Fijian Pattern L

(Dixon 1988:123)

In consequence, whatever the condition on subjects is that requires them to be headed by an overt article in Boumaa Fijian, Pattern A possessors are subject to it while Pattern L possessors are not. Hence, again, Pattern A possessors behave as clausal structural case-marked DPs do, whereas Pattern L possessors do not.

The last piece of evidence in support of the hypothesis that Pattern A possessors are assigned structural case while Pattern L possessors are not comes from Palauan. Palauan has two different morphosyntactic means to mark (definite) complements, depending on the aspect of the verb. In perfective constructions, the verb agrees with the object (32). In imperfective constructions, in contrast, the object is introduced by the linker er (33) (Georgopoulos 1991:29).

ak-uldenges-terir [a resensei er ngak].

Palauan

1SG-PERF.honor-3PL ART teachers L me

(Georgopoulos 1991:29)

'I respected my teachers.'

ak-uleldanges [er a resensei er ngak].

1SG-IM.honor L ART teachers L me

'I respected my teachers.'

It is remarkable to see that the alternation between object-agreement and introducing the object by means of a linker is completely parallel to the one found in possession structures: in this regard, we could say that (32) illustrates Pattern A at the clausal level, while (33) illustrates Pattern L. But what is more relevant for our discussion is that er also precedes oblique phrases:

Ke-mle er tia er oingerang?

Palauan

R.2SG-comeL here L when

'When did you come here?'

(Georgopoulos 1991:27)

That is, in Palauan, Pattern L possessors, together with the object DPs of imperfective verbs, are to be grouped with oblique phrases, contrary to Pattern A possessors, which, as subjects and objects of perfective verbs, are not introduced 


\section{Structural Case and the Typology of Possessive Constructions}

by a linker. This illustrates how, in fact, the distinction between Pattern A and Pattern L possessors parallels the distinction between DP arguments (with structural case) and DP/PP adjuncts (with no structural case).

The different pieces of data presented in this section all converge in one direction: in all the languages under analysis, some possessors but no all behave like clausal structural case-marked arguments, showing a distinction between Pattern A and other types of pattern (Pattern L in the Austronesian languages and the Imbabura Quechua DP). This result, in turn, provides evidence in favor of the case condition on pro-drop and extraction of possessors (20) as way to account for the crosslinguistic correlation between agreement, extraction and dropping of possessors found in the generalization that I proposed in (19).

\section{References}

Abney, Steve. 1987. The English Noun Phrase in its Sentential Aspect. Ph.D. diss., Massachusetts Institute of Technology, Cambridge, MA.

Aissen, Judith. 1987. Tzotzil Clause Structure. Dordrecht: Kluwer.

Baker, Mark. 1996. Polysynthesis Parameter. New York: Oxford University Press.

Béjar, Susana. 2003. Phi-Syntax: A Theory of Agreement. Ph.D. diss., University of Toronto, Canada.

Bianchi, Valentina. 2006. On the Syntax of Person Arguments. Lingua 116:20232067.

Chomsky, Noam. 2000. Minimalist Inquiries: The Framework. In Martin, Michaels and Uriagereka, eds., Step by Step, 89-155. Cambridge, MA: Massachusetts Institute of Technology Press.

Chomsky, Noam. 2001. Derivation by Phase. In M. Kenstowicz, ed., Ken Hale: A Life in Language, 1-52. Cambridge, MA: Massachusetts Institute of Technology Press.

Chung, Sandra. 1991. Functional Heads and Proper Government in Chamorro. Lingua 85:85-134.

Chung, Sandra. 1998. The Design of Agreement. Chicago: University of Chicago Press.

Cole, Peter. 1985. Imbabura Quechua. London: Croom Helm.

Den Dikken, Marcel. 1999. On the Structural Representation of Possession and Agreement. In I. Kenesei, ed., Crossing Boundaries, 137-178. Amsterdam: John Benjamins.

Dixon, Robert M. W. 1988. A Grammar of Boumaa Fijian. Chicago: University of Chicago Press.

Duguine, Maia. 2007. On the Syntax of Possessors. Paper presented at the XVII Colloquium on Generative Grammar, Universitat de Girona.

Gavruseva, Elena. 2000. On the Syntax of Possessor Extraction. Lingua 110:734772. 
Maia Duguine

George, Leland and Jaklin Kornfilt. 1981. Finiteness and Boundedness in Turkish. In F. Heny, ed., Binding and Filtering, 105-128. London: Croom Helm.

Georgopoulos, Carol. 1991. Syntactic Variables. Dordrecht: Kluwer.

Hermon, Gabriella. 1985. Syntactic Modularity. Dordrecht: Foris.

Johns, Alana. 1992. Deriving Ergativity. Linguistic Inquiry 23(1):57-87.

Lefebvre, Claire and Pieter Muysken. 1988. Mixed Categories: Nominalizations in Quechua. Dordrecht: Kluwer.

Rizzi, Luigi. 1990. Relativized Minimality. Cambridge, MA: Massachusetts Institute of Technology Press.

Sánchez, Liliana. 1996. Why does Southern Quechua Agree in Person Nominally? Ms., Carnegie Mellon University.

Schütze, Carson. 1997. INFL in Child and Adult Languages: Agreement, Case and Licensing. Ph.D. diss., Massachusetts Institute of Technology, Cambridge, MA.

Schütze, Carson. 2001. On the Nature of Default Case. Syntax 4(3):205-238.

Szabolcsi, Anna. 1994. The Noun Phrase. In F. Kiefer and K. Kiss, eds., Syntax and Semantics 27: The Syntactic Structure of Hungarian, 179-274. New York: Academic Press.

Maia Duguine

HEIS, Faculty of Philology and History-Geography

EHU/UPV

5, Unibertsitateen ibilbidea

01006 Vitoria-Gasteiz, Basque Country

maia.duguine@ehu.es 